\title{
Co-Culture Anoxygenic Photosynthetic Bacteria With Bacillus sp. Isolated From Hanura Beach Against Vibrio sp.
}

\author{
Sumardi, Salman Farisi, Christina Nugroho Ekowati, Sundari Ayu Oktalia \\ Jurusan Biologi FMIPA Universitas Lampung, \\ Jl. Soemantri Brojonegoro, Gedung Meneng, Bandar Lampung, 35145, Lampung, Indonesia \\ *Email sumardi bio@yahoo.co.id
}

\begin{abstract}
A mangrove forest ecosystem is a place where many special Bacillus sp. found. This study aims to obtain Bacillus sp. isolates that can inhibit the growth of Vibrio sp. This study was conducted by selecting 77 Bacillus sp. isolates from the Hanura mangrove forest area. In addition, selected bacteria were tested for salt stress, $\mathrm{pH}$ stress, pathogenicity test, and antibiotic susceptibility test. Selected isolates were cultivated together with Vibrio sp. for 7 days. Bacillus sp. and Vibrio sp. cultured again with the addition of anoxygenic photosynthetic bacteria for 4 days. From the results of the initial selection, 4 isolates could inhibit the growth of Vibrio sp. The final results showed that Bacillus IL2K8 isolates were known to inhibit the growth of Vibrio sp., can grow at salinity $0 \%, 3 \%, 6 \%$ and $\mathrm{pH} 7$ and $\mathrm{pH} 10$. IL2K8 isolates are not pathogenic, resistant to amplicin antibiotics, streptomycin, nalidixic acid, and chloramphenicol but sensitive to trimethoprim antibiotics. In the joint culture of liquid media IL2K8 together with Anoxygenic Photosynthetic Bacteria (APB) isolates IL2K8 can inhibit the growth of Vibrio sp.
\end{abstract}

Keywords: antibacterial, Bacillus sp., BFA, mangrove, Vibrio sp.

\section{PENDAHULUAN}

Kendala yang sering terjadi dalam budidaya ikan dan udang adalah munculnya serangan penyakit yang disebabkan oleh organisme patogen seperti bakteri. Penggunaan antibiotik sering digunakan sebagai solusi menanggulangi masalah ini. Namun pemberian antibiotik ternyata memunculkan masalah baru yaitu terjadinya resistensi antibiotik. Bakteri probiotik yang dapat menghasilkan antibiotik alami dapat menjadi solusi yang lebih baik.

Penggunaan bakteri probiotik sebagai agen biokontrol dapat menjadi solusi dari permasalahan penyakit terhadap budidaya laut (Samosir et. al, 2017). Probiotik merupakan mikroorganisme hidup yang dalam jumlah yang cukup memberikan manfaat bagi kesehatan tubuh dan memiliki pengaruh menguntungkan karena asosiasinya dengan inang (Wardika et. al, 2014 dan Anurogo, 2014). Bakteri probiotik mampu menghasilkan asam laktat, hidrogen peroksida, dan bakteriosin yang dapat berfungsi sebagai antimikroba dan antibiotik yang mampu menekan pertumbuhan bakteri pathogen (Samosir et. al, 2017). Bakteri Bacillus dapat dijadikan kandidat probiotik karena dapat hidup pada berbagai kondisi, salah satunya dapat hidup pada ekosistem mangrove. Bakteri dari genus Bacillus, Bifidobacteri, Pseudomonas, Lactobacillus, Micrococcus, Afifella dan Rhodobacter dapat dijadikan sebagai kandidat probiotik dalam saluran pencernaan hewan terutama hewan akuatik (Feliatra dan Suryadi, 2004; Chumpol et. al, 2017).

Bacillus sp. diketahui memiliki kemampuan menghasilkan antimikroba yang dapat menghambat pertumbuhan bakteri patogen (Sumardi et. al, 2012), karena kemampuannya dalam menghasikan antibiotik tersebut bakteri Bacillus dapat dimanfaatkan sebagai kandidat probiotik penghasil antibakteri alami yang dapat menghambat pertumbuhan bakteri Vibrio sp. dan dapat menjadi salah satu solusi bagi permasalahan dalam usaha budidaya perairan. Bakteri Vibrio spp. merupakan salah satu bakteri yang sering menimbulkan masalah dalam budidaya perairan. Tujuan dari penelitian ini adalah untuk mendapatkan isolat bakteri Bacillus sp. dari kawasan hutan mangrove 

yang mampu menghasilkan antibakteri penghambat vibrio $s p$.

\section{METODE PENELITIAN}

Bahan yang digunakan dalam penelitian ini antara lain pepton, ekstrak khamir, gliserol, agar, air laut, garam fisiologis 0,98\%, garam dapur, $\mathrm{NaOH} 1 \mathrm{M}, \mathrm{HCl} 1 \mathrm{M}$, kristal violet, akuades, disk antibiotik trimetoprim, disk antibiotik streptomisin, disk antibiotik kloramfenikol $30 \mu \mathrm{g}$, ampisilin $10 \mu \mathrm{g}$, streptomisin $10 \mu \mathrm{g}$, trimetoprim $5 \mu \mathrm{g}$, dan asam nalidiksat $30 \mu \mathrm{g}$, media Agar Darah, Sea Water Complete dan Thiosulfate Citrate Bile Salts Sucrose. Isolat yang digunakan yaitu 77 isolat Bacillus sp. yang diisolasi dari lumpur, daun, dan perakaran mangrove Hanura, bakteri Vibrio sp. dan isolat Bakteri Fotosintetik Anoksigenenik (BFA) koleksi dari Laboratorium Mikrobiologi Jurusan Biologi Fakultas Matematika dan Imu Pengetahuan Alam Universitas Lampung.

\section{Seleksi Isolat Bacillus sp. Penghasil Antibakteri Penghambat Vibrio sp.}

Setiap isolat dan bakteri uji Vibrio sp. dibuat menjadi suspensi cair sebanyak 10 $\mathrm{ml}$ di dalam tabung reaksi, untuk selanjutnya diuji dengan menggunakan metode Kirby Bauer. Suspensi Vibrio sp. dimasukkan ke dalam cawan petri dengan metode pour plate. Kemudian di atas medium yang berisi bakteri Vibrio $s p$. dimasukkan kertas cakram yang telah dicelupkan ke dalam isolat bakteri Bacillus sp. Selanjutnya biakan diinkubasi pada suhu ruang selama 3 hari. Daerah terang atau zona jernih yang terbentuk menandakan bahwa isolat mampu menghambat pertumbuhan bakteri Vibrio sp. Zona jernih diukur menggunakan jangka sorong dan selanjutnya isolat yang menunjukkan daerah terang atau jernih dipilih untuk dilakukan karakterisasi (Sari et. al, 2015).

\section{Karakterisasi Isolat Bacillus sp.}

Karakterisasi isolat Bacillus sp. meliputi: uji cekaman terhadap kadar garam; uji cekaman terhadap $\mathrm{pH}$; uji patogenisitas; dan uji kepekaan antibiotik.
Uji cekaman terhadap kadar garam

Isolat Bacillus diambil menggunakan jarum ose steril kemudian diinokulasi ke dalam media SWC Agar yang dimodifikasi dengan garam konsentrasi $0 \%$; $3 \%$; dan $6 \%$. Kultur kemudian diinkubasi selama 24 jam pada suhu ruang. Pengamatan dilakukan dengan mengukur diameter koloni yang tumbuh (Triyanto et. al, 2009)

\section{Uji cekaman terhadap $\mathrm{pH}$}

Isolat Bacillus diambil menggunakan jarum ose steril kemudian diinokulasi ke dalam media SWC Agar yang dimodifikasi dengan $\mathrm{pH} 4, \mathrm{pH} 7$, dan $\mathrm{pH}$ 10. Kemudian diinkubasi selama 24 jam pada suhu ruang. Pengamatan dilakukan dengan mengukur diameter koloni yang tumbuh (Triyanto, et. al, 2009). Isolat yang menunjukan pertumbuhan yang baik selanjutnya dipilih untuk dilakukan uji selanjutnya.

\section{Uji patogenisitas}

Patogenesitas ditentukan melalui uji hemolitik pada medium agar darah. Isolat Bacillus diambil menggunakan jarum ose steril kemudian diinokulasi ke dalam media SWC Agar Darah. Kultur kemudian diinkubasi selama 24 jam pada suhu ruang. Pengamatan dilakukan dengan melihat zona yang terbentuk disekitar koloni atau perubahan warna media (Hamtini, 2014). Uji hemolitik positif menunjukkan karakter patogen pada isolat. Isolat yang tidak menunjukan sifat patogen dipilih untuk dilakukan uji selanjutnya.

\section{Uji kepekaan antibiotik}

Isolat diuji kepekaannya terhadap 5 jenis antibiotik antara lain kloramfenikol $30 \mu \mathrm{g}$, ampisilin $10 \mu \mathrm{g}$, streptomisin $10 \mu \mathrm{g}$, trimetoprim $5 \mu \mathrm{g}$, dan asam nalidiksat 30 $\mu \mathrm{g}$ dengan menggunakan metode KirbyBauer. Bakteri uji diinokulasi secara swab pada media SWC Agar cawan petri. Kemudian disk dari 5 jenis antibiotik diletakkan pada cawan kultur menggunakan pinset steril dan diinkubasi pada suhu ruang selama 24 jam. Pengamatan dengan melihat zona jernih yang terbentuk disekitar disk antibiotik (Hamtini, 2014 dan Puspitasari et. al, 2017). 


\section{Uji Kompatibel Isolat Bacillus sp. dan Vibrio sp dalam Media SWC Cair}

Uji kompatibel yang dilakukan merupakan metode kultur bersama modifikasi dari metode Vaseeharan dan Ramasamy (2003). Suspensi cair Isolat Bacillus sp. dan Vibrio sp. dengan kepadatan $10^{3}$ sel $/ \mathrm{ml}$ dimasukkan ke dalam $50 \mathrm{ml}$ media SWC cair. Sebagai kontrol isolat Bacillus sp.dan Vibrio sp. ditumbuhkan masingmasing pada media SWC cair. Selanjutnya diinkubasi pada orbital shaker dengan kecepatan 100 RPM pada suhu ruang selama 7 hari. Setiap hari kultur diambil untuk dihitung kepadatan jumlah Vibrio kontrol dan perlakuan yang tumbuh. Kultur dibuat pengenceran hingga seri $10^{-3}$ kemudian $1 \mathrm{ml}$ dari setiap seri pengenceran diinokulasikan secara pour plate ke dalam media TCBS. Setelah inkubasi selama 24 jam kepadatan Vibrio sp. dihitung secara langsung. Kontrol Bacillus dihitung dengan membuat seri pengenceran sampai dengan $10^{-6}$, lalu diambil $1 \mathrm{ml}$ dari pengenceran $10^{-4}, 10^{-5}$, dan $10^{-6}$ lalu diinokulasikan secara pour plate ke dalam media SWC agar dan diinkubasi selama 24 jam lalu dihitung secara langsung.

Uji Kompatibel Isolat Bacillus sp., Vibrio sp. dan BFA dalam Media SWC Cair

Suspensi isolat Bacillus dan BFA dengan kepadatan $10^{5} \mathrm{sel} / \mathrm{ml}$ dan Vibrio $\mathrm{sp}$. sebanyak $10^{3} \mathrm{sel} / \mathrm{ml}$ ke dalam $16 \mathrm{ml}$ media SWC cair lalu diinkubasi secara anaerob, pemberian cahaya lampu dan pada suhu ruang selama 4 hari. Kontrol isolat Bacillus, Vibrio sp.dan BFA yang ditumbuhkan secara terpisah dengan kepadatan yang sama dengan perlakuan.

Selanjutnya kultur perlakuan dan kontrol vibrio diambil dan dibuat pengenceran sampai dengan $10^{-2}$ kemudian diambil $1 \mathrm{ml}$ dari setiap pengenceran untuk diinokulasikan secara pour plate ke dalam media TCBS. Kontrol dibuat seri pengenceran hingga $10^{-7}$ lalu diambil $1 \mathrm{ml}$ dari pengenceran $10^{-5}, 10^{-6}$, dan $10^{-7}$ lalu diinokulasikan secara pour plate ke dalam media SWC agar.

Setelah inkubasi selama 24 jam kepadatan Vibrio sp. perlakuan dan kontrol dihitung secara langsung. Semua perlakuan dibuat dalam tiga ulangan.

\section{HASIL DAN PEMBAHASAN}

Seleksi dan Karakterisasi Isolat Bacillus sp. Penghasil Antibakteri Penghambat Vibrio sp.

Setelah dilakukan seleksi dari 77 isolat, didapatkan 4 jenis isolat Bacillus sp. yang positif menghasilkan zona jernih (Tabel 1). Zona jernih yang terbentuk menandakan adanya reaksi penghambatan pertumbuhan bakteri Vibrio sp. hal ini dapat terjadi karena munculnya zat antibakteri dari isolat bakteri Bacillus sp. yang dapat menghambat pertumbuhan bakteri bersifat Gram negatif. Zona jernih pada media dapat terbentuk karena bakteri Vibrio tidak dapat tumbuh disekitar koloni isolat Bacillus. Isolat yang menunjukan pertumbuhan yang baik pada cekaman garam ekstrim yaitu isolat IL2K8 dan ID2K1 (Tabel 1). Selain itu isolat IL2K8 dan ID2K1 juga menunjukkan pertumbuhan yang baik pada $\mathrm{pH} 7$ dan 10, namun tidak ada isolat yang tumbuh pada $\mathrm{pH} 4$ (Tabel 1).

Bakteri dapat tumbuh dalam kadar garam yang luas dengan cara mempertahankan keseimbangan osmotik selnya (Marihati et. al, 2014). Bakteri juga dapat tumbuh dalam kisaran konsentrasi ion hidrogen $(\mathrm{pH})$ yang luas dari $\mathrm{pH} 2$ hingga 9. Bedasarkan ketahanannya terhadap $\mathrm{pH}$, bakteri dibedakan menjadi bakteri asidofilik yaitu bakteri yang hidup pada $\mathrm{pH}$ asam, bakteri alkalofilik yaitu bakteri yang hidup pada $\mathrm{pH}$ basa dan bakteri neutralofilik yaitu bakteri yang hidup pada $\mathrm{pH}$ normal. Bacillus merupakan jenis bakteri bersifat neutrofilik yang dapat hidup dalam kisaran $\mathrm{pH} 5$ hingga 9. Bakteri netrofilik pada umumnya tidak dapat tumbuh pada $\mathrm{pH}$ yang terlalu asam atau terlalu basa, namun bakteri ini dapat tetap bertahan hidup dengan melakukan homeostasis $\mathrm{pH}$ atau kemampuan mikroba untuk mengontrol $\mathrm{pH}$ internalnya agar dapat bertahan (Moat et. al, 2002). Pengaruh pH terhadap pertumbuhan bakteri berkaitan dengan aktivitas enzim. Enzim dibutuhkan bakteri untuk mengkatalis reaksi metabolisme yang berhubungan dengan pertumbuhan 
bakteri, antara lain enzim RNA polimarase, yang berperan dalam proses transkripsi pada sintesis protein. Apabila $\mathrm{pH}$ dalam suatu medium atau lingkungan tidak optimal maka akan mengganggu kerja enzim tersebut (Suriani et. al, 2013). Konsentrasi ion $\mathrm{H}^{+}$akan meningkat apabila $\mathrm{pH}$ di lingkungan asam, ion $\mathrm{H}^{+}$ini akan mempengaruhi sisi aktif enzim (Ottolenghi, 1970).

Transpor ion-ion esensial akan terhambat apabila $\mathrm{pH}$ di lingkungan menjadi asam, hal ini terjadi karena permeabilitas membran terhadap ion proton naik sehingga sel tidak mampu menghasilkan Adenosin Trifosfat (ATP) dan terjadi kegagalan proses respirasi menyebabkan pertumbuhan sel lambat kemudian mati (Wang et. al, 1079)

Kemampuan bakteri untuk tumbuh pada cekaman lingkungan yang ekstrim menunjukkan bahwa isolat dapat bertahan pada berbagai kondisi lingkungan. Kemampuan bakteri probiotik untuk hidup pada kondisi ekstrim diperlukan untuk hidup dengan baik di dalam maupun di luar tubuh organisme inang (Triyanto, 2009).

Setelah dilakukan uji cekaman terhadap kadar garam dan $\mathrm{pH}$ didapatkan 2 isolat yang dapat dilanjutkan pada uji patogenisitas. Isolat yang memiliki sifat patogen dilihat dari tingkat kejernihan yang terbentuk pada media agar darah. Isolat ID2K1 diketahui memiliki sifat a (alfa) hemolisis dan isolat IL2K8 memiliki sifat $Y$ (gamma) hemolisis (Tabel 1).

Hemolisis darah dibagi dalam 3 jenis, yaitu alfa $(\alpha)$ hemolisis, beta $(\beta)$ hemolisis dan gamma ( $\gamma$ ) hemolisis. alfa $(\alpha)$ hemolisis merupakan kemampuan melisiskan sebagian sel darah merah dan hemoglobin, beta $(\beta)$ hemolisis yaitu yang mampu melisis seluruh sel darah merah dan hemoglobin, gamma $(\mathrm{\gamma})$ hemolisis yaitu yang tidak menunjukan kemampuan hemolisis apapun [9]. Bakteri yang bersifat hemolitik dapat menghasilkan metabolik sekunder yang dapat melisiskan sel darah. Hemolisin merupakan salah satu zat yang dihasilkan bakteri yang dapat melisiskan darah. Hemolisin diketahui dapat menghancurkan hemoglobin dan mengurangi jumlah eritrosit dalam darah (Le Marechal et. al, 2011). Kemampuan bakteri dalam menghemolisis darah merupakan salah satu faktor virulensi yang umum dimiliki oleh bakteri patogen (Lestari et. al, 2016).

Bacillus sp. IL2K8 tidak memiliki sifat patogen. Isolat tersebut selanjutnya diuji kepekaan terhadap antibiotik menggunakan lima jenis antibiotik yaitu ampisilin, streptomisin, trimetoprim, asam nalidiksat dan kloramfenikol. Dari hasil uji didapatkan kepekaan yang berbeda terhadap antibiotik. Isolat diketahui peka terhadap antibiotik trimetoprim dan bersifat resisten terhadap ampisilin, streptomisin, kloramfenikol dan asam nalidiksat (Tabel 1). Isolat IL2K8 peka terhadap antibiotik trimetoprim. Antibiotik trimetoprim berfungsi menghambat sintesis asam folat. Resistensi suatu bakteri terhadap antibiotik dapat disebabkan oleh adanya mutasi gen dalam kromosomnya dan atau plasmidnnya (Sudigdoadi, 2015).

Bakteri yang memiliki gen-gen resistensi akan mengekspresikan enzim yang secara spesifik dapat menghancurkan atau menghalangi keefektifan antibiotikantibiotik tertentu. Gen resistensi tersebut dibawa oleh plasmid yang dikenal sebagai plasmid $\mathrm{R}$ atau resistensi (Campbell et. al, 2012). Hal ini didukung oleh pernyataan Sudigdoadi (2015) bahwa bakteri yang resisten terhadap kloramfenikol dapat menghasilkan enzim kloramfenikol asetiltransferase yang dapat merusak aktivitas dari kloramfenikol. Pembentukan enzim ini berada dibawah kontrol plasmid.

Resistensi bakteri terhadap antibiotik dapat memiliki dampak positif dan negatif. Salah satu sifat probiotik yang baik yaitu tahan terhadap antibiotik (Malago et. al, 2011). Sedangkan dampak negatifnya adalah apabila isolat bakteri bermutasi dari bakteri nonpatogen menjadi patogen, seperti pada percobaan yang dilakukan Frederick Grifith dalam Campbell (2012) yang menunjukan bahwa bakteri Streptococcus pneumoniae nonpatogen dapat menjadi patogen apabila ditumbuhkan bersama Streptococcus pneumoniae patogen yang telah mati. Selain itu bakteri patogen juga 
dapat menjadi resisten terhadap antibiotik apabila bakteri mengambil plasmid dari bakteri yang memiliki kemampuan resistensi terhadap antibiotik. Penelitian menunjukkan bahwa gen resistensi antibiotika Stphylococcus epidermidis dapat dipindahkan ke Staphylococcus aureus dalam kondisi in vivo maupun in vitro (Forbes, dan Schaberg. 1983).

Bakteri patogen diketahui dapat memperoleh gen resistensi antibiotik dari lingkungan melalui transfer gen horizontal yaitu tranformasi, transduksi atau konjugasi. Konjugasi dianggap memiliki pengaruh terbesar pada penyebaran gen resisten antibiotik (Wintersdorff et. al, 2016).

\section{Uji Kompatibel Isolat Bacillus sp. dan Vibrio sp. dalam Media SWC Cair}

Hasil yang didapatkan yaitu pertumbuhan bakteri isolat Bacillus sp. maupun Vibrio sp. bersifat fluktuatif. Namun, pertumbuhan isolat Bacillus lebih tinggi dibandingkan dengan Vibrio sp., hal ini karena isolat Bacillus sp. mampu menekan pertumbuhan bakteri Vibrio sp. walaupun tidak dapat membunuh Vibrio sp. sepenuhnya (Gambar 1). Isolat bakteri Bacilllus sp. tidak dapat membunuh bakteri Vibrio sp. dapat disebabkan karena sifat antibakteri yang dihasilkan oleh isolat hanya menghambat pertumbuhan bakteri lawan (bakteriostatik), tidak bersifat membunuh bakteri (bakterisidal) sehingga Vibrio sp. masih dapat tumbuh kembali. Hasil kultur bersama isolat Bacillus dan Vibrio sp. tidak menunjukkan penurunan pertumbuhan bakteri Vibrio yang signifikan, hal ini dapat tejadi karena beberapa faktor yang dapat mempengaruhi besar kecilnya aktivitas penghambatan zat antibakteri antara lain jenis dan umur dari bakteri penghasil bakteriosin dan bakteri uji (Noaman et. al, 2014). Antibiotik digolongkan sebagai metabolit sekunder yang dihasilkan oleh bakteri endofitik dan antagonis.

Antibiotik atau antibakteri memiliki
mekanisme
menghambat sel bakteri diantaranya dengan cara menghambat sintesa protein dan asam nukleat, perusakan dan penghambatan pembentukan dinding sel, perubahan permeabilitas sel target dan penghambatan kerja enzim yang berperan dalam pertumbuhan bakteri (Sudigdoadi, 2015). Bakteriostatik menghambat pertumbuhan bakteri namun tidak membunuh. Senyawa bakteriostatik umumnya menghambat sintesis protein pada sel bakteri (Madigan et. al, 2000). Pertumbuhan bakteri yang fluktuatif dapat dikarenakan bakteri mengalami pertumbuhan kembali setelah mengalami penurunan pertumbuhan. Hal tersebut disebabkan karena sel-sel bakteri lain yang telah mengalami kematian menghasilkan sumber nutrien baru, sel bakteri ini mengalami penguraian sehingga menghasilkan sumber nutrien baru yang dapat dimanfaatkan bakteri yang masih hidup sebagai bahan metabolismenya kembali (Respati et. al, 2017).

\section{Uji Kompatibel Isolat Bacillus sp., BFA dan Vibrio sp. dalam Media SWC Cair}

Isolat Bacillus sp. dan Vibrio sp. diuji kembali dengan kultur bersama dengan penambahan isolat BFA. Dari uji ini didapatkan hasil bahwa Vibrio sp. mengalami kematian setelah kultur bersama isolat IL2K8 dan BFA selama 4 hari. Pada kontrol Vibrio sp. jumlah sel akhir bakteri Vibrio sp. mengalami penurunan namun tidak lebih rendah dari perlakuan kultur bersama Vibrio sp. dengan isolat Bacillus IL2K8. Perlakuan dengan menambahkan BFA dan isolat

Bacillus sp. ternyata dapat membantu menghambat pertumbuhan Vibrio sp. hingga $100 \%$ (Tabel 2). Isolat Bacillus dengan BFA mampu menekan pertumbuhan Vibrio sp. karena BFA memiliki waktu hidup yang lebih lama dan isolat Bacillus memiliki zat anti mikroba yang dapat menghambat pertumbuhan Vibrio sp. Hal ini selaras dengan penelitian yang dilakukan Widiyanto et. al, 1998), yaitu bakteri BFA diketahui dapat menghambat pertumbuhan bakteri Vibrio harveyi. 
Tabel 1. Seleksi dan Karakterisasi Isolat Bacillus sp.

\begin{tabular}{|c|c|c|c|c|c|c|c|c|c|c|c|c|c|c|c|}
\hline \multirow{2}{*}{ Jumlah Isolat } & \multirow{2}{*}{$\begin{array}{c}\text { Uji Antagonis } \\
\text { Zona Jernih }\end{array}$} & \multicolumn{3}{|c|}{ Uji Cekaman Garam (\%) } & \multicolumn{3}{|c|}{ Uji Cekaman pH } & \multicolumn{3}{|c|}{ Uji Patogenisitas } & \multicolumn{5}{|c|}{ Kepekaan Antibiotik } \\
\hline & & 0 & 3 & 6 & 4 & 7 & 10 & $\alpha$ & $\beta$ & $\mathbf{Y}$ & A & Str & $\mathbf{T}$ & AN & C \\
\hline \multirow{4}{*}{$\begin{array}{l}\text { L111, L2I2, L2I3 } \\
\text { L214, .., .., } \ldots \\
\ldots, \ldots, \ldots, \ldots \\
\ldots, \ldots, \ldots, \ldots \\
\quad \ldots, \text { IL2K9 }\end{array}$} & $\mathrm{L} 214$ & + & + & + & - & + & + & TU & TU & TU & TU & TU & TU & TU & TU \\
\hline & A214 & - & - & + & - & - & - & TU & TU & TU & TU & TU & TU & TU & TU \\
\hline & ID2K1 & ++ & ++ & ++ & - & ++ & ++ & + & - & - & TU & TU & TU & TU & TU \\
\hline & IL2K8 & ++ & ++ & ++ & - & ++ & ++ & - & - & + & $\mathrm{R}$ & $\mathrm{R}$ & $S$ & $\mathrm{R}$ & $\mathrm{R}$ \\
\hline 77 & 4 & & 2 & & & 2 & & & 1 & & & & 1 & & \\
\hline
\end{tabular}

Keterangan; $\alpha=$ Hemolisis sebagian

$\beta=$ Hemolisis total

$\mathrm{Y}=$ Tidak terjadi hemolisis

$A=$ Ampisilin

Str = Streptomisin

$\mathrm{T}=$ Trimetoprim

AN = Asam Nalidiksat

$\mathrm{C}=$ Kloramfenikol

$\mathrm{TU}=$ Tidak diuji

$\mathrm{R}=$ Resisten

$\mathrm{S}=$ Peka

$+\quad=$ Terjadi reaksi / Pertumbuhan koloni sempit

$++=$ Pertumbuhan koloni luas

- $\quad=$ Tidak terjadi reaksi

L2I4, A2I4, ID2K1, IL2K8 = Isolat Bacillus sp. 


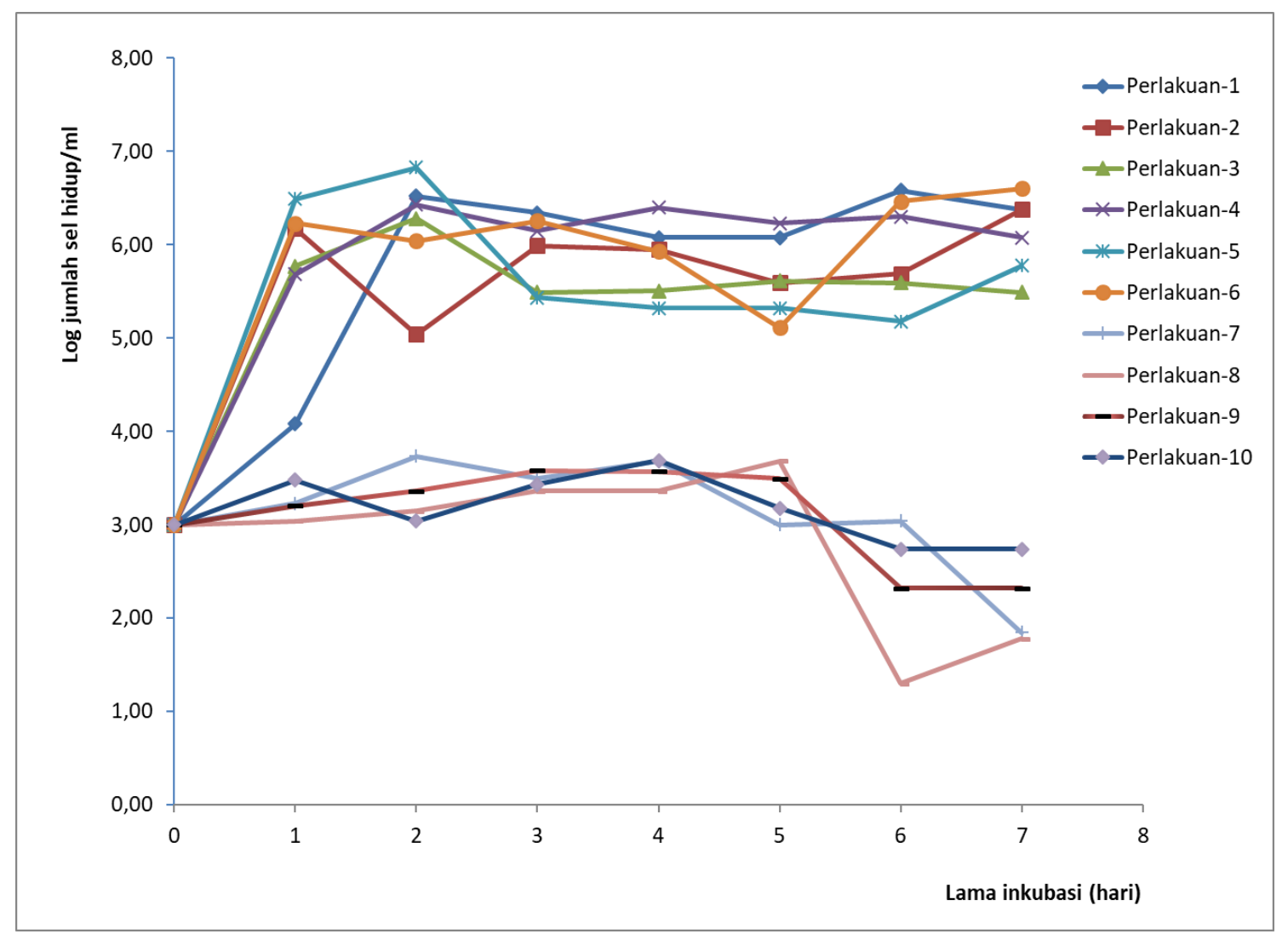

Gambar 1. Grafik pertumbuhan isolat Bacillus sp. (garis terang) dan Vibrio sp. (garis samar) setelah kultur bersama

Keterangan;

Perlakuan 1 = Pertumbuhan Isolat Bacillus ID2K1 (data hitung dari kultur bersama Isolat Bacillus ID2K1dan Vibrio sp.) Perlakuan 2 = Pertumbuhan Isolat Bacillus IL2K8 (data hitung dari kultur bersama Isolat Bacillus IL2K8 dan Vibrio sp.) Perlakuan 3 = Pertumbuhan Isolat Bacillus ID2K1 dan IL2K8 (data hitung dari kultur bersama Isolat Bacillus ID2K1 dan IL2K8 serta Vibrio sp.)

Perlakuan 4 = Pertumbuhan Isolat Bacillus ID2K1 (data hitung dari kultur Isolat Bacillus ID2K1)

Perlakuan $5=$ Pertumbuhan Isolat Bacillus IL2K8 (data hitung dari kultur Isolat Bacillus IL2K8)

Perlakuan 6 = Pertumbuhan Isolat Bacillus ID2K1 dan IL2K8 (data hitung dari kultur Isolat Bacillus ID2K1 dan IL2K8)

Perlakuan 7 = Pertumbuhan Vibrio sp. (data hitung dari kultur bersama Isolat Bacillus IL2K8 dan Vibrio sp.)

Perlakuan $8=$ Pertumbuhan Vibrio sp. (data hitung dari kultur bersama Isolat Bacillus ID2K1 dan Vibrio sp.)

Perlakuan 9 = Pertumbuhan Vibrio sp. (data hitung dari kultur bersama Isolat Bacillus ID2K1 dan IL2K8 serta Vibrio sp.)

Perlakuan $10=$ Pertumbuhan Vibrio sp. (data hitung dari kultur Vibrio sp.)

Tabel 2. Pertumbuhan Vibrio sp. Setelah Kultur Bersama

\begin{tabular}{|c|c|c|c|c|}
\hline \multirow{2}{*}{ Perlakuan } & \multicolumn{3}{|c|}{ Jumlah Sel Awal (sel/ml) } & \multirow{2}{*}{$\begin{array}{l}\text { Jumlah } \\
\text { Sel Vibrio } \\
\text { sp. Akhir } \\
\text { (sel/ml) }\end{array}$} \\
\hline & Vibrio & IL2K8 & BFA & \\
\hline A & - & $1 \times 10^{5}$ & - & - \\
\hline B & - & - & $1 \times 10^{5}$ & - \\
\hline C & $1 \times 10^{3}$ & - & - & $8,6 \times 10^{2}$ \\
\hline $\mathrm{D}$ & $1 \times 10^{3}$ & $1 \times 10^{5}$ & - & $1,2 \times 10^{2}$ \\
\hline$E$ & $1 \times 10^{3}$ & $1 \times 10^{5}$ & $1 \times 10^{5}$ & 0 \\
\hline
\end{tabular}

Keterangan;

$A=$ Isolat Bacillus IL2K8 (kontrol)

$\mathrm{B}=\mathrm{BFA}$ (kontrol)

$\mathrm{C}=$ Bakteri Vibrio sp. (kontrol)

$\mathrm{D}=$ Kultur Bersama Vibrio sp. dan Isolat

Bacillus IL2K8

$\mathrm{E}=$ Kultur Bersama Vibrio sp., Isolat

Bacillus IL2K8 dan BFA 


\section{KESIMPULAN}

Isolat Bacillus sp. IL2K8 adalah isolat yang diseleksi dari 77 isolat yang berasal dari lumpur kawasan hutan mangrove Hanura yang dapat menghambat pertumbuhan Vibrio sp. setelah diuji dengan metode Kirby Bauer. Isolat IL2K8 dapat tumbuh dengan kadar garam $0 \%, 3 \%, 6 \%$ dan nilai $\mathrm{pH} 7$ serta 10 . IL2K8 tidak memiliki sifat patogenitas, resisten terhadap antibiotik amplisin, striptomisin, asam nalidiksat dan kloramfenikol namun peka terhadap antibiotik trimetoprim. Dalam kultur bersama pada media cair isolat Bacillus IL2K8 bersama dengan bakteri fotosintetik anoksigenik dapat menghambat pertumbuhan Vibrio sp.

\section{DAFTAR PUSTAKA}

Anurogo, D. (2014). Probiotik: Problematika dan Progresivitasnya. Medical Review, 27(3), 46-57.

Campbell, N.A., J.B. Reece, L.A. Urry, M.L. Cain, S.A. Wasserman, P.V. Minorsky, R.B. Jackson. (2012). Biologi. Jakarta: Erlangga.

Chumpol S, D., Kantachote, T. Nitoda dan H. Kanzaki. (2017). The Roles Of Probiotic Purple Nonsulfur Bacteria To Control Water Quality And Prevent Acut Hepatopancreatic Necrosis Disease (AHPND) For Enhacement Growth With Higher Survival In White Shrimp (Litopenaeus vannamei) During Cultivation. Aquaqulture. Diakses dari https://www.sciencedirect.com/science/art icle/pii/S0044848616312935

Feliatra E. dan E. Suryadi. (2004). Isolasi dan Identifikasi Bakteri Probiotik dari Kerapu Macan (Ephinephelus fuscogatus) dalam Upaya Efisiensi Pakan Ikan. Jurnal Natur Indonesia, 6(2), 75-80.

Forbes, B.A. dan D.R. Schaberg. (1983). Transfer of Resistance Plasmids from Staphylococcus epidermidis to Staphylococcus auereus: Evidence for Conjugative Exchange of Resistance. Journal of Bacteriology, 153(2), 627-634.

Hamtini. (2014). Isolation and Selection of Bacillus sp. from Catfish (Clarias sp.) as well Its potential as a Probiotic. Bogor: Institut Pertanian Bogor.

Le Marechal, C., Seyffert, N., Jardin, J., Hernandez, D., Jan, G., Rault, L., Azevedo V., Francois, P., Schrenzel, J., van de Guchte, M., Even, S., Berkova, N., Thiery, R., Fitzgerald, J.R., Vautor, E., Le Loir, Y. (2011). Molecular Basis of Virulence in Staphylococcus aureus mastitis. PloS One, 6, e27354.

Lestari, W.L., Agung B., Artini P. (2016). Bakteri Heterotrof Aerobik Asal Saluran Pencernaan Ikan Sidat (Anguilla bicolor bicolor) dan Potensinya sebagai Probiotik. Bioteknologi, 13(1), 9-17. doi: 10.13057/biotek/c130102.

Madigan, M.T., J.M. Martinko, J. Parker. (2000). Brock Biology of Microorganism. New Jersey : Prentice-hall. Inc.

Malago, J.J., J.G.L. Koninkx dan R. Marinsek. (2011). Probiotic Bacteria and Enteric Infection. Cyoptoprotection of Probiotic Bacteria. New York: Springer Dordrecht Heidelberg London.

Marihati., Nani, H., Muriyati., nilawati., Syarifudin, E., dan Danny, W, H.. (2014). Penggunaan Bakteri Halofilik Sebagai Biokatalisator Untuk Meningkatkan Kualitas Dan Produktifitas Garam Nacl Di Meja Kristalisasi. Jurnal Riset Industri. 8(3), 191 - 196.

Moat, A. G., J. W. Foster, dan M. P. Spector. (2002). Microbial Physiologi fourth edition. New York: Wiley-Liss, Inc.

Noaman, N. H., A. Fattah, M. Khaleafa dan S. $H$ Zaky. (2014). Factors Affecting Antimicrobial Activity of Synechococcus leopoliensis. Microbiological Research, 159 (4): 395-402. Diakses dari https://www.sciencedirect.com/science/a rticle/pii/S0944501304000722.

Ottolenghi. P. 1970). The Effect of Hydrogen Ion Concentration on The Simplest Steady-State Enzyme System. Biochem. J, 123, 445-453.

Puspitasari, Putra dan Handayani. (2017). Senyawa Antibiotik dari Bacillus $s p 1$ (HA1) yang Bersimbiosis pada Spon 
Laut Haliclona fascigera. Jurnal Sains Farmasi dan KliniS, 134-140.

Respati, N.Y., E. Yulianti dan A. Rakhmawati. (2017). Optimasi Suhu Dan pH Media Pertumbuhan Bakteri Pelarut Fosfat Dari Isolat Bakteri Termofilik. Jurnal Prodi Biologi, 6(7).

Samosir, M. F., D. Suryanto dan Desrita. 2017. Isolasi dan Identifikasi Bakteri Potensial Probiotik Pada Saluran Pencernaan Ikan Mas (Cyprinus Carpio). Jurnal Bidang Manajemen Sumberdaya Perairan, 15(1).

Sari, Ranap J., Feliatra dan D. Yoswaty. (2015). The Antagonists Test of Probiotic Bacteria Isolated from Black Tiger Shrimp (Penaeus monodon fabricus) Against Pathogens Pseudomonas sp, Aeromonas hidrophyla, Vibrio alginolyticus. Jurnal Online Mahasiswa, 2(1).

Sudigdoadi, Sunarjati. (2015). Mekanisme Timbulnya Resistensi antibiotik Pada Infeksi Bakteri. Mikrobiologi Fakultas Kedokteran. Bandung: Universitas Padjajaran.

Sumardi, C.N. Ekowati, K. Handayani, Nurhayati. (2012). Isolasi Dan Karakterisasi Bacillus sp. Penghasil Antimikroba dari Saluran Pencernaan Ayam Kampung (Gallus domesticus). Prosiding SNSMAIP III-2012. ISBN No. 978-602-98559-1-3.

Suriani, Sanita., Soemarno, dan Soeharjono. (2013). Pengaruh Suhu dan Ph terhadap Laju pertumbuhan Lima Isolat Bakteri Anggota Genus Pseudomonas yang diisolasi dari Ekosistem Sungai Tercemar Deterjen di sekitar Kampus Universitas Brawijaya. J-PAL, 3(2).
Triyanto, Isnansetyo, A., Prijambada, I. D., Widada, J., dan Tarmiawati, A. (2009). Isolasi, Karakterisasi Dan Uji Infeksi Bakteri Proteolitik Dari Lumpur Kawasan Hutan Bakau. Jurnal Perikanan, XI(1), 13-18.

Vaseeharan, B. dan Ramasamy, P. (2003). Control Of Pathogenic Vibrio Spp . By Bacillus Subtilis BT23 , A Possible Probiotic Treatment For Black Tiger Shrimp Penaeus Monodon. The Society of Applied Microbiolog, 83-87.

Wang, D.I.C., Clooney, C.L., Demain, A.L., Dunnil, P., Humprey, A.E. dan Lily, M.D. (1979). Fermentation and Enzym Technology. John Wiley and Sons. New York.

Wardika, A. S., Suminto, dan Sudaryono, A. (2014). Pengaruh Bakteri Probiotik Pada Pakan Dengan Dosis Berbeda Terhadap Efisiensi Pemanfaatan Pakan, Pertumbuhan dan Kelulushidupan Lele Dumbo (Clarias Gariepinus). Journal of Aquaculture Management and Technology, 3(4), 9-17.

Widiyanto, T., Suwantol, A., Adidjuwana, H., dan Kaswadji, R. (1998). Kemampuan Bakteri Fotosintetik Anoksigenik Dalam Menurunkan Konsentrasi $\mathrm{H}_{2} \mathrm{~S}$ dan Menghambat Pertumbuhan Vibrio harveyi. Jurnal Bioteknologi Pertanian, 3(1), 17-22.

Wintersdorff CJHv, J. Penders, J.Mv. Niekerk, N.D. Mills, S. Majumder, L.Bv. Alphen, P.H.M. Savelkoul, P.F.G. Wolffs. (2016). Dissemination of Antimicrobial Resistance in Microbial Ecosystems through Horizontal Gene Transfer. Frontiers in Microbiology, 7, 173. 